\title{
Post Mining Application: Tuzluca Rock Salt Mine Therapy Center for Health Tourism
}

\author{
Okan Özbakır ${ }^{1, *}$, Mustafa Öcal ${ }^{2}$, Mehmet Hakkı Alma ${ }^{3}$ \\ ${ }^{1}$ Vocational School of Higher Education for Technical Sciences, Mining Programe, Igdır University, Igdır, Turkey \\ ${ }^{2}$ Vocational School of Higher Education for Technical Sciences, Machine Programe, Igdır University, Igdır, Turkey \\ ${ }^{3}$ Igdır University, Igdır, Turkey
}

Received May 26, 2021; Revised June 25, 2021; Accepted July 25, 2021

\section{Cite This Paper in the following Citation Styles}

(a): [1] Okan Özbakur, Mustafa Öcal, Mehmet Hakk Alma, "Post Mining Application: Tuzluca Rock Salt Mine Therapy Center for Health Tourism," Natural Resources and Conservation, Vol. 9, No. 1, pp. 1 - 7, 2021. DOI: 10.13189/nrc.2021.090101.

(b): Okan Özbakır, Mustafa Öcal, Mehmet Hakkn Alma (2021). Post Mining Application: Tuzluca Rock Salt Mine Therapy Center for Health Tourism. Natural Resources and Conservation, 9(1), 1 - 7. DOI: 10.13189/nrc.2021.090101.

Copyright $\bigcirc 2021$ by authors, all rights reserved. Authors agree that this article remains permanently open access under the terms of the Creative Commons Attribution License 4.0 International License

\begin{abstract}
The rapid development of technology coupled with the increases in population led to requirement of raw materials. For that reason, the largest quantity of production is needed but the large production causes significant social, economic and ecological consequences regarding a sustainable mining activity. Preserving the relevant balances reveals the necessity of developing sustainable projects after mining. Thus, development or sustainable development should be defined not only as increasing the welfare level, but also as protecting human rights, political rights and ecological balance, and leaving a liveable world to future generations. Herewith present study, Tuzluca rock salt mine was been assessed. Due to being located on the Silk Road, Tuzluca (Igdir, Turkey) rock salt mine with its rich reserves and tenors has been of great economic importance since ancient times. Within the areas of this salt mine, the production is still being carried out but the relevant and safe areas are under project for salt therapy purposes. Due to the unique properties of the salt mine and underground air, and its therapeutic ability potential, these areas have been assessed for health tourism, viz. Speleotherapy and Halotherapy center. These treatments are known to be very beneficial for respiratory tract, ear, nose, throat and skin diseases within the framework of complementary medicine applications. However, we should herein note that mining activities carried out might bring significant consequences regarding the social and ecological structures of the region. With the ongoing increase in mining activities, it has enabled the necessary investments, employment, education, trade and
\end{abstract}

infrastructure for the residential area to develop over time. Along with the present project, we have aimed at developing and providing a sustainable prosperity and a safe future after salt mining activities, also aiming at making significant contributions to the region.

Keywords Rock Salt Mining, Sustainable Mining, Speleotherapy, Halotherapy, Health Tourism

\section{Introduction}

Mining consists of exploration and preparation processes, as well as production and ultimately environmental regulation. The risk of being finally found or postponed at any time at the said stages reveals the necessity to attach importance to risk analysis and evaluation during the planning stages. It is worthy to utter herein that mining is a long but ending business in itself either because the resource is depleted or the operation is not economical. In fact, mining activities cause a wide range of alterations in the ecological environment and its irreversibility afterwards [1].

While an error that can be made in determining the geological structure or reserve may threaten the existence of the enterprise, the emergence of financial problems, changes in production costs, movements in market prices, etc. It can cause adverse effects on mining activities [2]. Any attempts relating an error during determination of 
geological structure or reserve might lead to consequences and changes such as the existence of the enterprise, emergence of financial problems, production cost, and fluctuations in market price. Those, subsequently cause adverse effect on mining activities. Sustainable mining is possible by ensuring stable market conditions and realizing strategic plans and programs that can use national assets effectively and efficiently. All processes of mining activities should be integrated into strategic planning, especially post-mining operations should be carefully emphasized and it should be aimed at minimizing the possible negative consequences [3]. In that context, we furthermore have to develop the ability to meet the needs of future generations without sacrificing the resources we have while meeting today's needs [4] means that ensuring and sustainability of a permanent supply for the foundation of permanent prosperity both with and after mining activities are of great targets. The relevant targets should be addressed not only on ecological balance but also its social and economic aspects of the region. Within this framework, it is possible to express sustainability as being able to benefit as many people as possible as social sustainability, economic sustainability with developing stability and wealth, and environmental sustainability with the need to protect nature after developing consciousness [5].

Projects and programs to be developed after mining require high levels of talent, vision, manners and skills as well as high motivation. Today, many attempts and relevant projects have been applied in many parts of world [1]. The systems in which pit waters are used, the arrangement of open pits as new racing areas for motor sports, the use of land for solar power plants, ponds and green areas are of the main examples. Such applications are generally developed for post coal and quarry operations due to their proximity to residential areas.

The view of the recently abandoned rock salt mines as a potential resource for the storage of oil or natural gas is among the frequently mentioned issues. The low permeability and porosity of rock salt and its self-healing ability as well as its suitable mechanical properties have been the main reasons why it is sought after. However, the fact that it has an accelerating effect on open metal requires the correct selection of the material or container to be stored in rock salt. As a matter of fact, in 1967, medium level radioactive waste was stored in Asse Salt mines in Germany, and later the salt-water solution formed as a result of the mixture of surface water caused the barrels to corrode rapidly and the resulting leakage mixed with the groundwater [6].

The Polish Wieliczka Salt Mine, which is accepted as a world heritage, was opened to tourism after nearly a thousand years of known salt production and became a center of attraction with its nature, crystal cave, Holy Cross
Chapel and salt water baths. Romania's Prahova Salt Mine, which has the feature of being the largest salt mine in Europe, is an important center in the treatment of respiratory diseases today with its 14 galleries and contributes to the country's economy in terms of health tourism [6]. In the galleries with ceiling heights exceeding 55 meters, sculptures of important historical characters and different motifs carved from salt are exhibited [6].

The use of mine galleries for health tourism, and the climatic conditions of underground conditions were discovered in the 18th century as the respiratory complaints of miners decreased over time and increased rapidly after the Second World War.

The use of mine galleries for health tourism and the climatic conditions of underground conditions were discovered in the 18th century as the respiratory complaints of miners decreased over time and increased rapidly after the Second World War. Speleotherapy which is referred to as respiratory therapy in underground cavities, balneotherapy and hydrotherapy, have opened new horizons in terms of the use of structures abandoned after mining [7]. Perm in Russia, Soligorsk in Belarus, potash mines, karstic cavities in Slovakia, Gasteiner Heilstollen and Badgastein-Bockstein karst and granite caves in Austria, Solotivo in Ukraine, Tirgu Ocna in Romania, Wieliczka in Poland, Chon-Tus in Kyrgyzstan, Duz Dag in Nakhichevan are operated as salt mine therapy centres or clinics [8].

In 2017, Çankırı rock salt mines, which have a production history of thousands of years, were brought to tourism in our country, and in a short time, more than ten thousand visitors were hosted per month [9]. The fact that salt sculptures of famous sculptors are exhibited in the galleries promoted as Underground Salt City and organizations for health tourism supported by various activities are an important example within the framework of economic and social sustainability after mining [6].

Herewith the project, we aimed at making the area as a brand in the region with Speleotherapy and Halotherapy Practices, Daily Visits and Cave Tourism and Education Practices. The project is regarded as one of the rare projects developed and implemented in order to make permanent and sustainable investment and management in cooperation with the state, university and private sector.

\section{Tuzluca Example and Project Area}

Tuzluca belonging to Igdir province at the and south of the border of Turkey with Armenia, $39 \mathrm{~km}$ west of Igdir province, between 38.35 north latitude and 43.07 east longitude (Figure 1). The altitude is $975 \mathrm{~m}$ and the harsh continental climate is dominant. The temperature changes between -19 and +37 degrees throughout the year. 


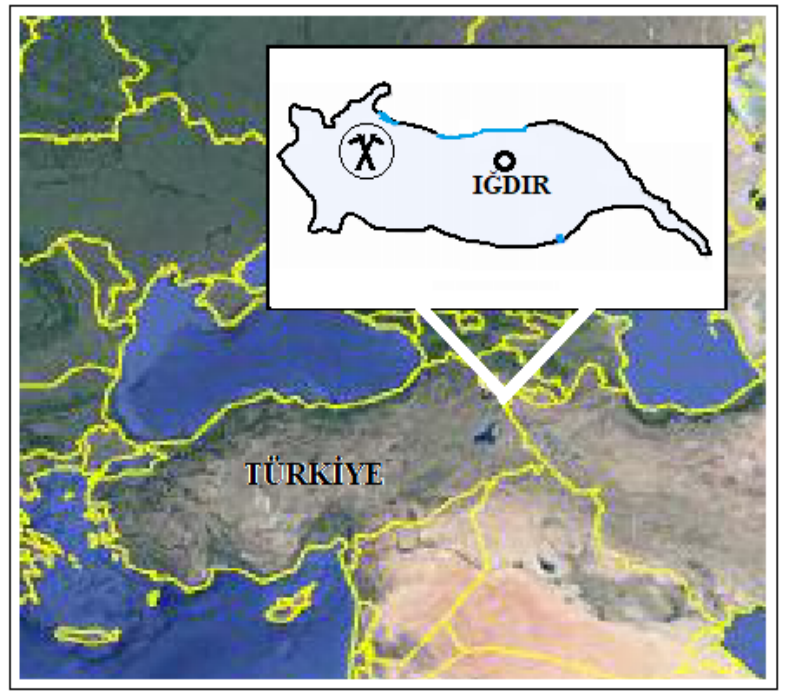

Figure 1. Stratigraphy of Iğdır province

The structure, which is located in the east of the district, Pliocene aged and which consists of claystone and marl alternation at the top covering an area of approximately $7-8 \mathrm{~km}^{2}$, thick-bedded, lens bands and grey gypsum in the middle, and thick-layered salt at the bottom is named
Tuzluca formation (Figure 2). The Cincevat Formation, which consists of an alternation of older sandstone, conglomerate, and mudstone, is located below [10]. The rock salt outcropping in the northeast of Tuzluca is wedged to the east and spreads over an area of $4 \mathrm{~km}^{2}$ and the vein thickness is around $100 \mathrm{~m}$. In the studies carried out by MTA, it has been determined that the Tuzluca rock salt deposit has $91.4 \% \mathrm{NaCl}$ grade, the visible reserve is 613 million tons and the possible reserve is 226 million tons [11].

The salt mines, which have a history of almost a thousand years, have passed through the hands of many civilizations and operators and have become today, a $6 \mathrm{~km}$ production line has been completed and the room is in the form of heels. The mine is reached by the gallery (Entrance of The Therapy Center), which was opened in the $30^{\circ} \mathrm{NE}$ direction, $3.5 \mathrm{~m}$ wide and $200 \mathrm{~m} \mathrm{long}$, and there are rooms with ceilings of $6-8 \mathrm{~m}$ in salt and widths of approximately $8-8.5 \mathrm{~m}$. The production carried out by the chamber-heel method consists of blasting rock salt and transporting the material released by trucks.

During the study, perspective view of the area was obtained with drones. The data obtained were digitized and a topographic map of the region was drawn.
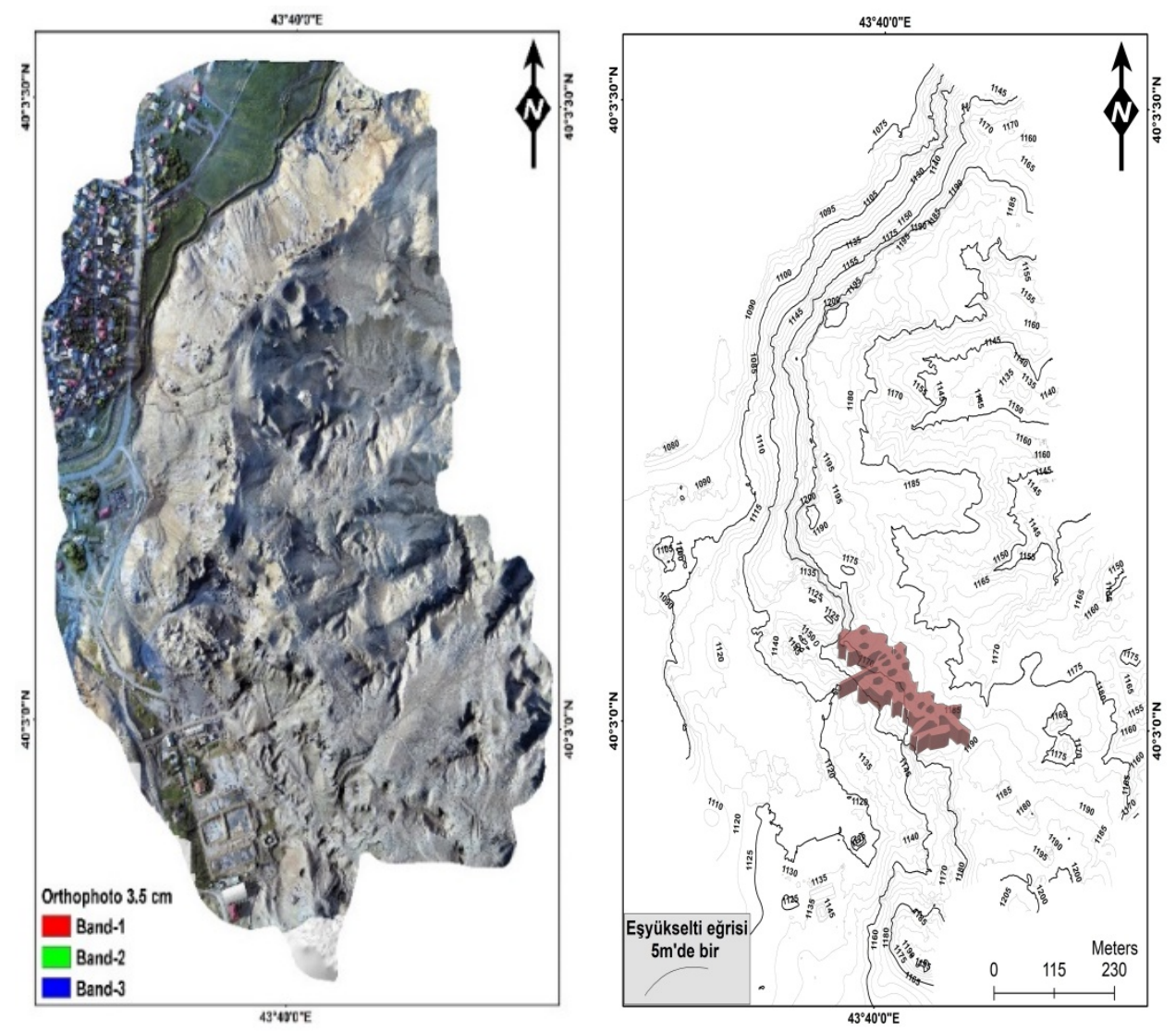

Figure 2. Perspective and topographic view of the project area 

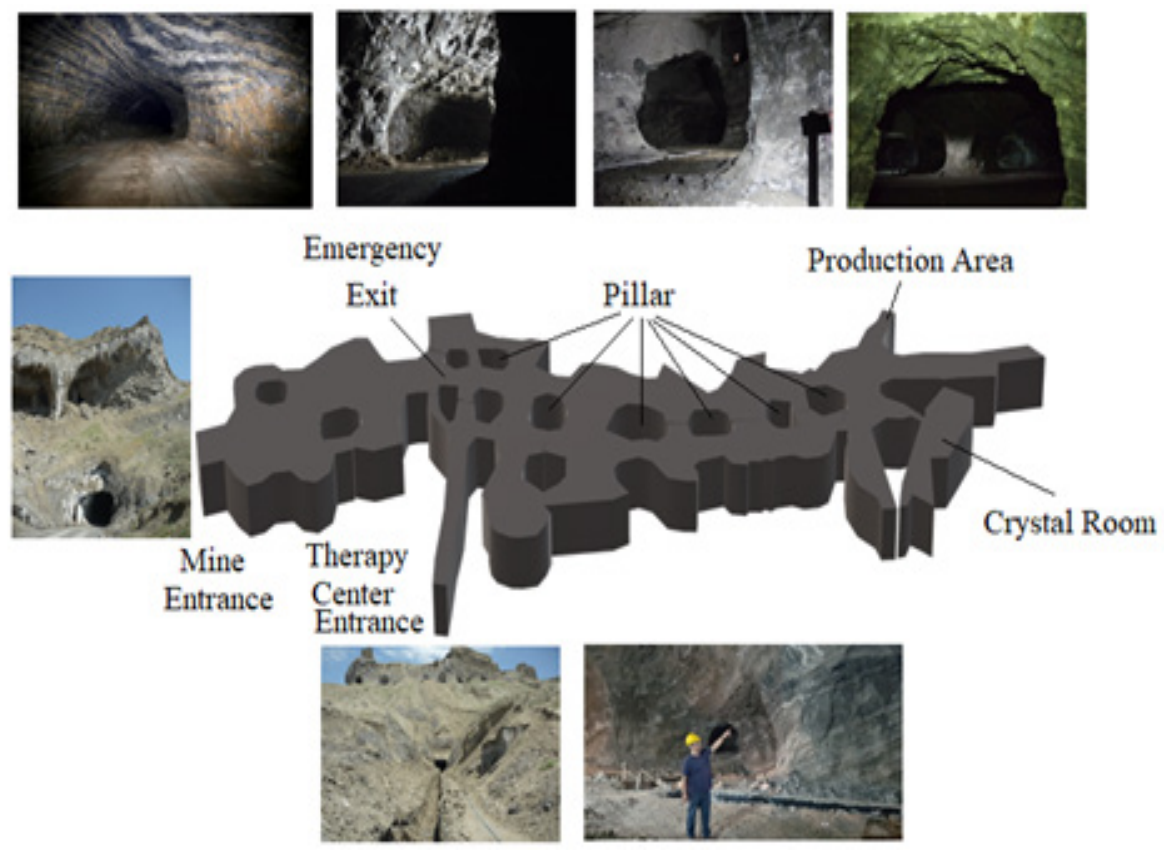

Figure 3. The space for the therapy center.

The area, which is separated as a therapy center and isolated from the production area, is approximately 55 acres and is surrounded by clay and marl mounds and old production cavities [10]. Gypsum lenses and salt layers are observed in places (Figure 3).

Inside the galleries, the surfaces of the excavation have been cleaned with the effect of water and moisture in time, and the polished plugs and foliations have become evident. The cracks were filled with salt again with the effect of water and repaired and filled the gaps by crystallizing. As a result of the evaporation of water in some cavities in the mine, very smooth salt crystals of various sizes formed the crystal chamber by crystallizing especially on the sidewalls and floor of the gallery [12].

\section{Materials and Methods}

The project of bringing salt caves in Tuzluca district to health tourism, the special importance of the caves region, the absence of any application and the nature of the area where the project will be implemented is a special project area. Currently, production activities in the mining area are carried out by private company. During the implementation of the project, no intervention will be made to the activities and productions at the mine and necessary measures will be taken to prevent disruptions. Project implementations will be made in the salt mine production gaps located in the caves [13].

The main purpose of the design of the salt caves, which are already very impressive in terms of natural richness, is to protect the existing cave surfaces and to provide a natural museum experience with light shadow effects, as well as to design places where visitors can socialize and relax during this visit. While designing the cave, care has been taken to ensure that the materials used are natural and modern [14]. In this context, the main walkways are covered with wood. Gabion wall and precast wall panels are used as wall material. Both of these materials play an important role in completing the design with ease of manufacture and modern appearance and aesthetics [15].

The project design is spread over a total area of 21.18 hectares. In order to meet the needs of the visitors at the entrance of the project site, an open car park for forty vehicles has been designed. In the administrative building, administrative units, souvenir sales points, health personnel rooms and other technical volumes were designed to operate the cave [13].

According to the layout plan, the entrance to the cave is reached by passing between two small hills. It is aimed for the visitors to visit the cave after passing through the administrative unit, and the presence of two hills in front of the cave entrance complicates this design idea. Because, if the administrative building is located at the beginning of the cave entrance, the retaining walls to be built between the hills and the building will have a serious effect on the construction cost. However, this problem was turned into an advantage by building a tube passage between the administrative building and the cave entrance. Thus, the construction investment cost will be reduced and at the same time, it will contribute to the visuality of the project (Figure 5). 

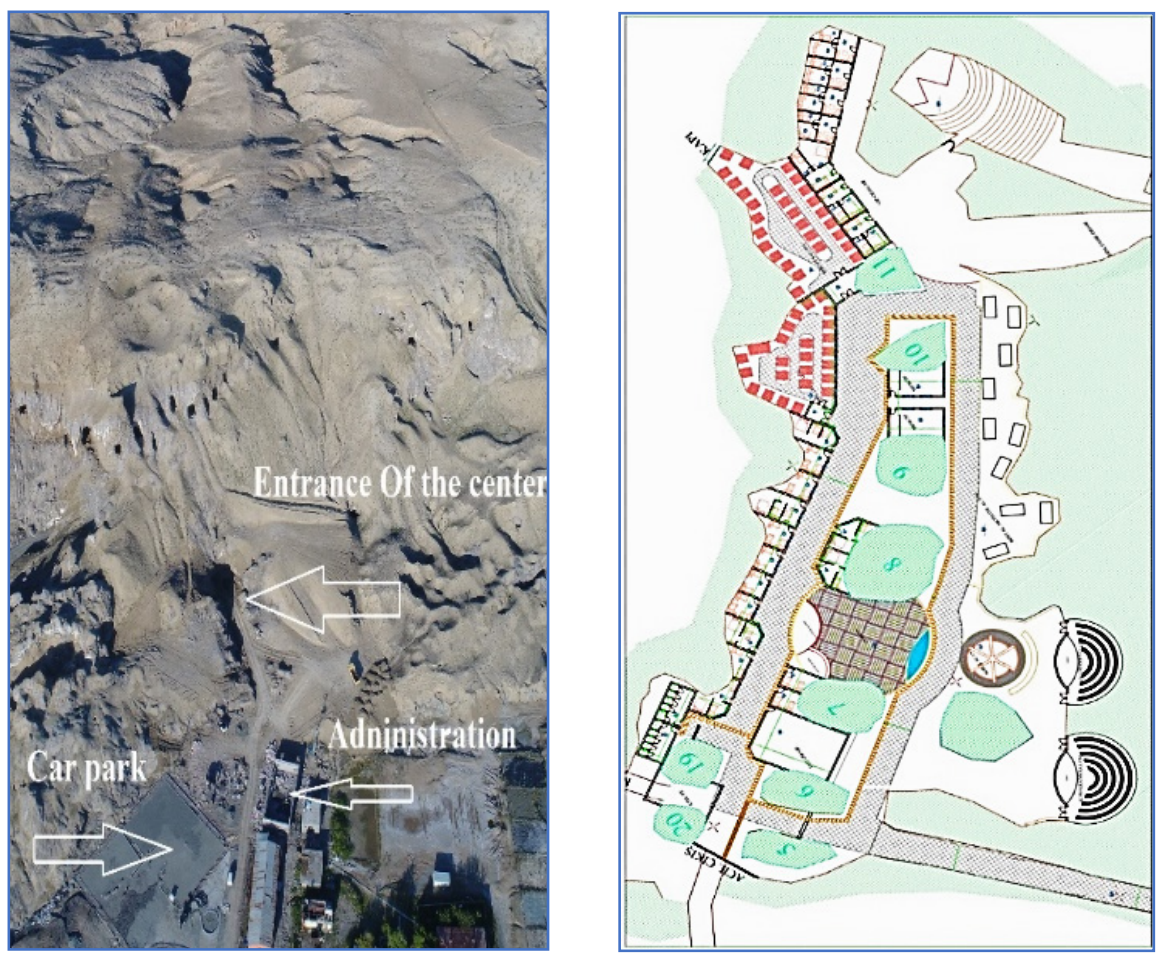

Figure 4. Overview of the project and the mine
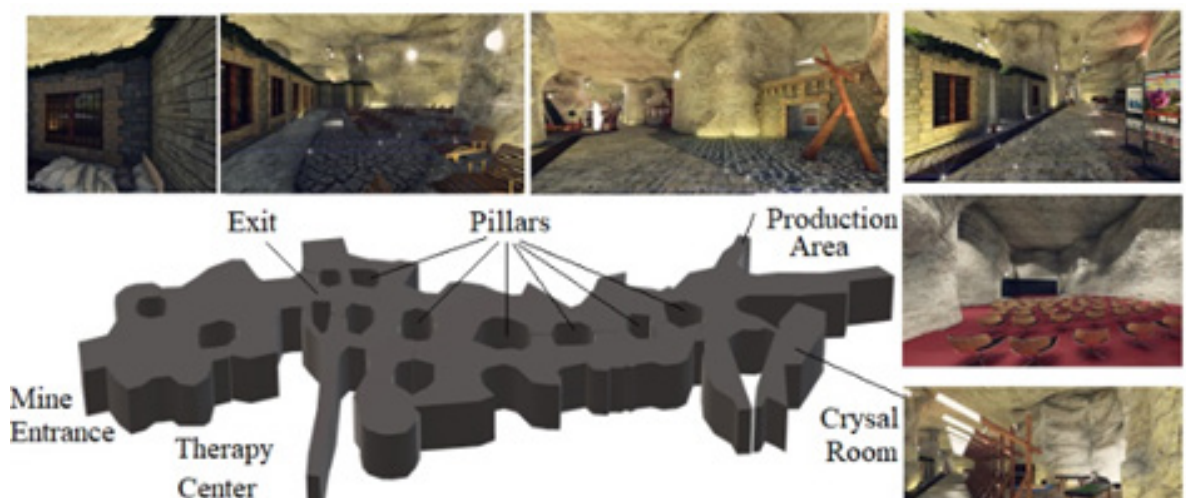

Center

Entrance
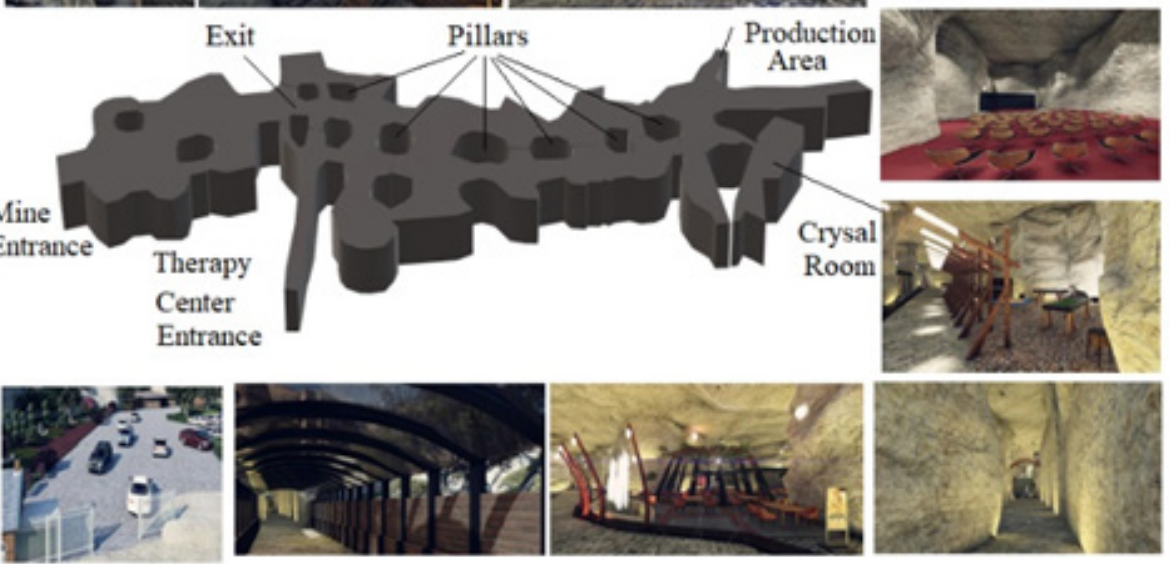

Figure 5. All planned facilities and construction project

Inside the cave, the existing state was preserved by not touching the walls as much as possible, and floor coverings were defined only in certain places. Since it is aimed that the people entering the cave spend as much time as possible in the cave, many activities have been included in the cave. While designing the interior of the cave, quotations were made from the history of mining. The high and wide hall of the cave is reached after the narrow and long entrance corridor (Figure5).

The first of the two main halls is on the right at the end of the narrow corridor. At the entrance of this large and high hall, a 96-seat cafeteria and a kitchen serving here are designed.

Visitors will be able to watch the exhibition icon made of steel construction that stands right in front of them and points to the original in history while resting in the cafeteria.

A 138-person conference hall was designed in the corner behind the exhibition icon, which is both close to the entrance of the cave and located in a more private area. In this way, the participants coming for the conference and the visitors coming for treatment will be prevented 
from disturbing each other.

The social activity area will welcome the visitors as they move from the cafeteria and exhibition icon into the cave. This area will be enriched with various board games and activities, allowing visitors to have fun.

After the masjids, the crystal room, which will perhaps impress the visitors the most, is reached. Salt crystals that take years to form in this section will be presented to the visitors. The floor of this room, which is inclined as a natural structure, is cascaded as an amp.

When going straight from the main entrance corridor without deviating to the right, the second main hall, which forms the other part of the design, is reached. The street created by this hall has been handled mostly for sick visitors. The patient rooms on this street have been diversified for two and three persons. These rooms are designed with precast panel walls, and VIP rooms at the end of the street are designed with gabion walls. Patient rooms are semi-open spaces where visitors who receive treatment in collective therapy rooms or who spend time in the salt therapy room can relax [13].

The salt therapy room, located on the left at the entrance of the street, is the place where the patients are treated by blowing the salt divided into particles with the help of machine equipment into the room again with the help of the machine. Towards the end of the street, there are collective therapy halls for men and women. These halls are equipped with sunbed-style furnishings, where visitors can receive therapy either in company with expert health personnel or alone.

Considering the cave design and operation, many technical infrastructures are needed. However, the salt mine will corrode and deform the installations to be used in these areas. For this reason, the entire cave infrastructure was transported to the relevant units by passing through the gallery spaces surrounded by insulation materials and the materials were taken under protection.

\section{Results and Discussion}

Undoubtedly, a developing country has to use its natural resources effectively and efficiently. While doing this, environmental and social impacts of any attempts should not be ignored. Since the environmental and social issues are intertwined, depletion of natural resources along with the increases in population is increasing. In that context, for the efficiency use of resources without any substantial damage should be provided for not only for welfare of human but also natural resources. At this point, the use of modern methods and equipment should be encouraged for mining activities to have clear goals for all parties and to operate more environmentally sensitive with less harmful results. In addition to its guiding, legislative and supervisory role, the state should encourage new investments and projects in this area, especially considering the impact of mining on economic and social development.

As seen in the salt therapy center risk analysis results, it is understood that the project is feasible despite possible negative developments. On the other hand, since the risk analysis is made considering the financial calculations, the importance of the implementation of the project increases, even more, when the social benefit is also taken into account

The economic analysis was not done with the aim of revealing the benefits and costs that the project brought to the investor institution in general, but it was understood that the project was profitable with many activities included. Due to the strong social aspect of the project, besides the income-generating activities that form the basis of the economic and financial analysis section in the feasibility report, there are many activities that contain social benefits. For example, it is thought that the social benefit of the studies for bringing the Salt Caves to tourism and the applied research activities to be carried out here will be more than the economic benefit. On the other hand, since the activities expected to occur in the project area and the contribution to rural development will require a subjective judgment, concrete values could not be obtained. Therefore, while evaluating the economic analysis, taking the social benefit of the project and creating new employment areas into account are also important.

\section{REFERENCES}

[1] Kretschmann, J., Efremenkov, A. B., A Khoreshok, A., "From Mining to Post-Mining: The Sustainable Development Strategy of the German Hard Coal Mining Industry", Earth and Environmental Science, 2017, DOI:10.1088/1755-1315/50/1/012024.

[2] Yaylaci, E.D., Düzgün, H.Ş., "Madencilik Sektörü için Sürdürülebilirlik Kriterleri”, Madencilik ve Çevre Sempozyumu Antalya, 2015. https://www.researchgate.net/ publication/311706179 Madencilik Sektoru icin Surduru lebilirlik_Kriterleri_Sustainability_ČCriteria_for_the_Minin g_Sector_in_Turkish

[3] Goldan, T., Danciu, C., Nistor, C., "Touristic And Medical Facilities In Romanian Salt Mine Cavities", Research Journal of Agricultural Science, 2010, vol. 42 (3), pp. 579-586.

https://www.researchgate.net/publication/228984351_TO URISTIC AND MEDICAL FACILITIES IN ROMANI AN_SALT_MINE_CAVITIES

[4] Koldaş, K.S., "Sürdürülebilir Madencilik ve Çevre: Örnek Bir Model", Madencilik ve Çevre Sempozyumu, Ankara, 2005, pp. 39-42. https://www.maden.org.tr/resimler/ekler/ 65f2ecd2900ba6a_ek.pdf

[5] Demirbugan, A., "Madencilikte Sürdürülebilir 
Rehabilitasyon Yaklaşımı Lusatia Linyit Havzası Deneyim”, Ulusal Çevre Bilimleri Araştırma Dergisi, 2020, vol.3(2) pp.68-73. https://dergipark.org.tr/en/download/arti cle-file/1108603

[6] Top 10 Largest Salt Mines In The World, American Mine Services https://americanmineservices.com/top-10-largestsalt-mines-in-the-world (accessed Jan.15, 2019)

[7] Karagülle, M. Z., M. Karagülle 2017, "Speleoterapi/Mağara Tedavi; Tuzluca Örneği, 1.Uluslararası Tuz Terapi Çalıştayı", Iğdır, pp. 37-38. https://www.igdir.edu.tr/Addo ns/Resmi/ uploads/files/336I.\%20ULUSLARARASI\%20T UZ\%20TERAP\%C4\%B0\%20\%C3\%87ALI\%C5\%9ETAY I\%20K\%C4\%B0TAP\%C3\%87I\%C4\%9EI\%20YAYINDA .pdf

[8] Engineer Live, Everything Yonu Need to Know About Salt Mines,https://www.engineerlive.com/content/everything-y ou- need-know-about-salt-mines (accessed May.21, 2020).

[9] Çankırı Belediyesi, Tuz Mağarası, https://www.cankiri. bel.tr/tuz-magarasi, 7, 1055, 1 (accesed Apr. 5,2020)

[10] Yılmaz, O., "Kağizman (Kars)-Tuzluca (Iğdir) Tuz Yataklarının Jeolojisi”, Mineralojisi ve Petrografisi, Yüksek Lisans Tezi, İzmir, 2007. https://acikerisim.deu.edu.tr/xmlui/bitstream/handle/20.50 $0.12397 / 8564 / 213064$.pdf? sequence $=1$ \&isAllowed $=\mathrm{y}$

[11] Uygun, A., "Türkiye Evoporitleri, Yeryuvarı ve İnsan", Ankara, 1980, pp. 89-94. https://dergipark.org.tr/tr/downlo ad/article-file/1157855
[12] Akgün, A., Ertaş, F., Akkaş, Ö., Yilmaz, İ., "Effects of Salt Caves On Human Life And Other Organisms", 1.Uluslararası Tuz Terapi Çalıştayı, Iğdır, 2017, pp. 22-31. https://www.igdir.edu.tr/Addons/Resmi/uploads/files/336I. $\%$ 20ULUSLARARASI $\% 20$ TUZ\%20TERAP $\%$ C4\%B0\%2 0\%C3\%87ALI\%C5\%9ETAYI\%20K\%C4\%B0TAP\%C3\% 87I\%C4\%9EI\%20YAYINDA.pdf

[13] Serhat Kalkınma Ajansı, “Tuzluca Tuz Mağaralarının Sağlık Turizmine Kazandırılması Fizibilitesi”, Iğdır Üniversitesi ve Mustafa Karakaş Mimarlık Şirketi, Iğdır, 2019. https://www.serka.gov.tr/assets/upload/dosyalar/tuzl uca-tuz-magaralarinin-saglik-turizmine-kazandirilmasi-fizi bilite-raporu.pdf

[14] Gül, Ü., "Deri Hastalıklarında ve Kozmetolojide Tuz Partikülü Ortamında Bulunma Tedavisi: Speleoterapi ve Haloterapi", 1.Uluslararası Tuz Terapi Çalıştayı, Iğdır, 2017, pp. 39-41. https://www.igdir.edu.tr/Addons/Resmi/u ploads/

files/336I.\%20ULUSLARARASI\%20TUZ\%20TERAP\% C4\%B0\%20\%C3\%87ALI\%C5\%9ETAYI\%20K\%C4\%B0 TAP\%C3\%87I\%C4\%9EI\%20YAYINDA.pdf

[15] Yildirim, B.I., Gürçam, Ö.S., Yildirim, F, “Tuz Mağarasının Turizme Kazandırılmasında Ekonomik ve Sosyo-Kültürel Etkiler: Yöre Halkı Tutumları", 1.Uluslararası Tuz Terapi Çalıștayı, Iğdır, 2017, pp. 8-13. https://www.igdir.edu.tr/Addons/Resmi/uploads/files/336I. $\%$ 20ULUSLARARASI\%20TUZ\%20TERAP\%C4\%B0\%2 0\%C3\%87ALI\%C5\%9ETAYI\%20K\%C4\%B0TAP\%C3\% 87I\%C4\%9EI\%20YAYINDA.pdf 